\title{
Brazilian Protocol for Sexually Transmitted Infections, 2020: infections that cause cervicitis
}

\author{
Angélica Espinosa Miranda ${ }^{[1]}$, Mariângela Freitas da Silveira ${ }^{[2]}$, Valdir Monteiro Pinto ${ }^{[3]}$, \\ Geralda Carolina Alves ${ }^{[1]}$ and Newton Sergio de Carvalho ${ }^{[4]}$
}

\author{
[1]. Ministério da Saúde, Secretaria de Vigilância em Saúde, Brasília, DF, Brasil. \\ [2]. Universidade Federal de Pelotas, Programa de Pós-Graduação em Epidemiologia, Pelotas, RS, Brasil. \\ [3]. Secretaria Estadual de Saúde de São Paulo, Programa Estadual de DST/Aids, São Paulo, SP, Brasil. \\ [4]. Universidade Federal do Paraná, Departamento de Tocoginecologia, Curitiba, PR, Brasil.
}

\begin{abstract}
Infections that cause cervicitis are a topic presented in the "Clinical Protocol and Therapeutic Guidelines for Comprehensive Care for People with Sexually Transmitted Infections", published by the Brazilian Ministry of Health in 2020. The document was developed based on scientific evidence and validated in discussions with experts. This article presents epidemiological and clinical aspects of infections that cause cervicitis and recommendations on screening, diagnosis, and treatment of affected people and their sexual partnerships. Also, it discusses strategies for surveillance, prevention, and control of these infections for health professionals and health service managers involved in the programmatic and operational management of sexually transmitted infections. Expanding access to diagnostic tests and early treatment are crucial for controlling the spread of pathogens that cause cervicitis.
\end{abstract}

Keywords: Uterine cervicitis. Chlamydia infections. Gonorrhea. Ectropion. Therapeutics. Clinical protocols.

Highlighted excerpt: Associated factors to cervicitis: sexually active women younger than 25 years old, new or multiple sexual partners, partners with STI, previous history or presence of other STI, and irregular use of condoms.

\section{INTRODUCTION}

This article addresses the infections causing cervicitis, a topic that composes the Clinical Protocol and Therapeutic Guidelines (PDCT) for Comprehensive Health Care for People with Sexually Transmitted Infections (STI), published by the Health Surveillance Secretariat of the Brazilian Ministry of Health. The PDCT was developed by selecting and analyzing the available evidence from published documents and discussion in an experts' panel. The document was approved by the National Committee for Technology Incorporation to the Brazilian National Health System (Conitec) ${ }^{1}$ and updated by the specialists in STI in 2020 .

\footnotetext{
Corresponding author: Newton Sergio de Carvalho.

e-mail: newtonsdc@gmail.com

(D) https://orcid.org/0000-0001-7561-4566

Received 01 February 2021

Accepted 10 March 2021
}

\section{EPIDEMIOLOGICAL ASPECTS}

Cervicitis, also called endocervicitis, is an STI that causes inflammation and irritation of the cervix, recognized for the first time as a critical clinical issue in $1984^{2}$. Their most common agents are Chlamydia trachomatis and Neisseria gonorrhoeae. However, Trichomonas vaginalis, Mycoplasma genitalium, Ureaplasma urealiticum, and herpes simplex virus can also cause cervicitis ${ }^{3-5}$. It is essential to highlight that the cervix's outer segment's inflammation, mostly related to $T$. vaginalis, gives the uterine cervix a raspberry-like aspect that does not characterize cervicitis. It is considered an extension of vaginitis called colpitis macularis, even though it is located in the cervix ${ }^{6}$. Mechanical or chemical irritation also causes cervicitis in which no infection is identified. The mechanical irritation sources include trauma by surgical instruments or foreign objects (pessary, diaphragm, tampon, cervical cap, or condom). The chemical irritation can be caused by exposure to latex, vaginal douche, spermicide, or contraceptive creams ${ }^{7}$.

In 2016, estimates of the incidence of gonorrhea in LatinAmerica Countries indicated that the incidence in pregnant women was $0.5 \%$ in Argentina, $2.0 \%$ in the Bahamas, $1.0 \%$ in Brazil, up to $2.0 \%$ in Colombia, and Haiti, from $2.7 \%$ to $3.0 \%$. In non-pregnant 
women, in Brazil was $1.5 \%$, in Chile, $0.6 \%$, in Colombia, up to $0.2 \%$; and in Haiti, from $1.0 \%$ to $4.0 \%$. The estimate of the incidence of chlamydia in pregnant women in the Bahamas was $12.0 \%$; in Brazil, from $9.8 \%$ to $16.7 \%$; in Haiti, from 8.0 to $14.0 \%$; in Chile, $5.9 \%$, in Mexico, from $8.3 \%$ to $10.8 \%$; and in Peru, $10.0 \%$. In nonpregnant women, the estimate of Chlamydia incidence in Brazil was from $5.5 \%$ to $13.0 \%$; in Chile, $8.8 \%$; in Colombia, up to $3.2 \%$; in Haiti, from $1.9 \%$ to $11.6 \%$; in Mexico, $1.5 \%$; and in Suriname, $9.5 \%{ }^{8}$. In Brazil, there is no consolidated data at national level on the infections caused by $C$. trachomatis or $N$. gonorrhoeae, as they are not diseases with compulsory notification. A study carried out in six Brazilian states found prevalence rates of $2.1 \%$ of Chlamydia, $0.9 \%$ of gonorrhea, and $2.7 \%$ of chlamydia and gonorrhea coinfection in women living with the human immunodeficiency virus HIV ${ }^{9}$. In pregnant women and women looking for care in gynecology clinics $^{10-17}$, the prevalence rates are in accordance with the ones reported by the World Health Organization (WHO).

Seventy to $80 \%$ of cervicitis cases are asymptomatic. The most typical claims are vaginal discharge, intermenstrual or postcoital bleeding, dyspareunia, dysuria, frequent urination, and chronic pelvic pain ${ }^{18-23}$. The risk factors are sexually active women younger than 25 years old, new or multiple sexual partners, partners with STI, previous history or presence of other STI, and irregular use of condoms ${ }^{10,24-27}$.

\section{CLINICAL ASPECTS}

The symptoms of cervicitis can be similar to vaginitis, with vaginal discharge, pruritus, or dyspareunia. C. trachomatis and $N$. gonorrhoeae infections in women often do not produce vaginal discharge; however, if in the speculum examination, the presence of cervical mucous and cervical friability are observed, or if the swab test is positive, treatment for gonorrhea and Chlamydia must be performed, as those are the most frequent etiological agents of mucopurulent cervicitis ${ }^{3}$. Syndromic diagnosis of cervicitis is not effective for wide application, considering that it is asymptomatic in most $\operatorname{cases}^{28-30}$. The main consequences of cervicitis by Chlamydia and gonorrhea, when they are not treated, include pelvic inflammatory disease and its complications (chronic pelvic pain, ectopic pregnancy, and infertility) ${ }^{18}$. Cervical lesions caused by the herpes simplex virus and by syphilis can also cause cervicitis ${ }^{4}$. It is important to highlight that herpetic cervicitis is frequent in the primo-infection and it can be related to genital discharge ${ }^{3}$.

\section{DIAGNOSTIC}

Laboratory diagnosis of cervicitis caused by C. trachomatis and $N$. gonorrhoeae can be done by detecting the genetic component of infectious agents by molecular biology; it is the gold standard for symptomatic and asymptomatic $\operatorname{cases}^{31}$. The serology for Chlamydia can be applied in the diagnostic investigation of previous systemic infection, such as pneumonia in newborns, lymphogranuloma venereum, salpingitis, epididymitis, infertility, and ectopic pregnancy. Still, it is not used for diagnostic of urogenital investigation ${ }^{32}$. The screening, in Brazil, is recommended for pregnant women younger than 30 years old in the first prenatal care appointment, people with STI, and people living with HIV at the moment of the diagnostic, in addition to victims of sexual violence and users of pre-exposure prophylaxis (PrEP) and postexposure prophylaxis (PEP) to HIV. The inclusion of molecular biology tests for detecting $C$. trachomatis and $N$. gonorrhoeae is provided in the Brazilian National Health System (SUS) as a medium complexity procedure $02.02 .03 .099-7^{33}$.

C. trachomatis and $N$. gonorrhoeae infections can be diagnosed in women using first-void urine or by swab collection from the endocervix or vagina, including self-collected vaginal swabs. The nucleic acid amplification testing, NAAT are the most sensitive tests for this type of material. They are recommended for detection of C. trachomatis and $N$. gonorrhoeae ${ }^{30}$. As an example of NAAT, we can cite the polymerase chain reaction and the transcriptionmediated amplification. Examinations in other anatomic sites may be conducted in people with a history of receptive anal sex and oral sex. In $N$. gonorrhoeae, there is a possibility for culture conduction (modified Thayer-Martin selective medium). Still, this technique requires species collected with an endocervical swab, which is also available for detecting $N$. gonorrhoeae in the rectum, oropharynx, and eyes. The sensitivity of NAAT for detecting $N$. gonorrhoeae in urogenital and non-genital sites, in general, is higher than the one of culture ${ }^{34}$. Culture with a later test for determining the gonococcal susceptibility to antimicrobial drugs is also recommended in case of therapeutic failure ${ }^{31,35}$.

Laboratory diagnostic for $M$. genitalium must be ideally conducted through molecular biology tests since culture presents lower sensitivity and less convenience due to the too-long growth period $^{5}$.

\section{TREATMENT}

The clinical management of cervicitis cases is important for its effective control. The recommendations for the management of cervicitis, with a description of clinical routine, are presented in Figure 1. The drugs and regimes of treatment recommended ${ }^{33}$ are described in Figure 2.

Like the Brazilian protocol, the North-American one recommends, as a treatment for C. trachomatis, azithromycin $1 \mathrm{~g}$, per oral (PO), in a single dose, or doxycycline $100 \mathrm{mg}$, PO, twice a day, for seven days (not recommended for pregnant women) ${ }^{33,35}$. In cases of non-complicated infections in the cervix, urethra, and rectum caused by $N$. gonorrhoeae, the drug regime recommended by the PDCT is ceftriaxone $500 \mathrm{mg}$, intramuscular (IM), in a single dose, plus azithromycin $1 \mathrm{~g}$, PO, in a single dose, administered preferably simultaneously ${ }^{33}$. The recommended dose of ceftriaxone $500 \mathrm{mg}$ made by Conitec $^{34}$ was based on an assessment of cost-benefit regarding the use and financial impact of ceftriaxone $250 \mathrm{mg}$ in the country. Different doses of ceftriaxone, such as $250 \mathrm{mg}^{35}$, are recommended in other countries, according to drug availability and local data on drug susceptibility.

A challenge in treating $N$. gonorrhoeae is the increase of strains presenting clinical resistance to antimicrobial drugs, including cephalosporins, tetracycline, quinolones, and penicillins. Likewise, another agent that has shown high resistance to drugs is mycoplasma. Although the first-line treatment chosen is azithromycin, studies have shown up to $30 \%$ resistance in some places ${ }^{4}$. 


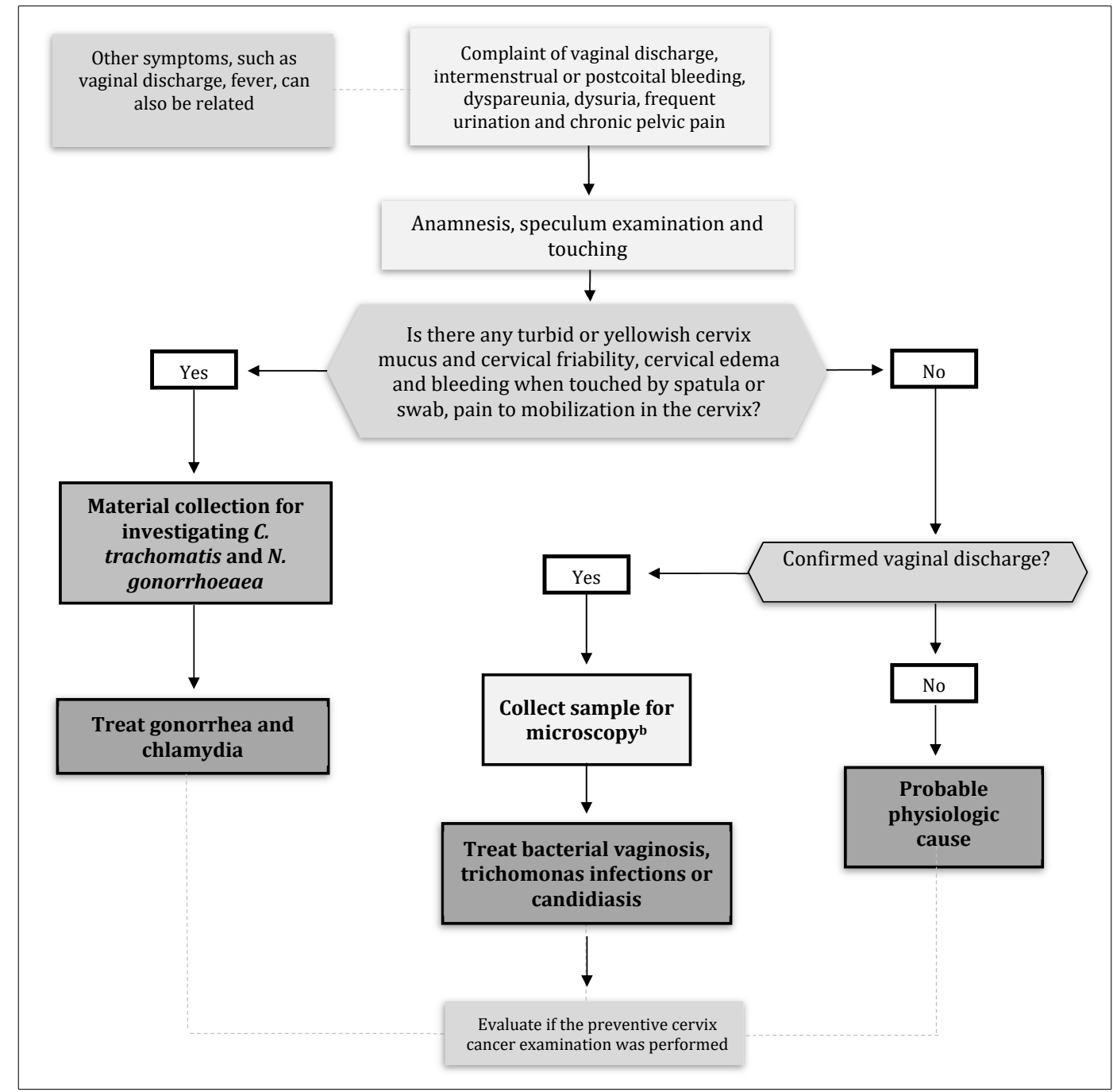

Source: adapted from Clinical Protocol and Treatment Guidelines for Comprehensive Health Care for People with Sexually Transmitted Infections, $2020^{33}$.

Notes: a) There are molecular biology kits detecting more pathogens simultaneously and Chlamydia and gonococcus and are also useful for diagnosing cervicitis, such as M. genitalium; b) Even in cases presenting normal cervical mucus and cervix, $C$. trachomatis and $M$. genitalium may be present; thus, molecular biology evidence, in case they are available, must be used to discard this possibility.

FIGURE 1: Recommendations for the management of symptomatic cervicitis.

\begin{tabular}{|l|l|}
\hline Gonorrhea/chlamydia & Treatment \\
\hline $\begin{array}{l}\text { NON-complicated gonococcal infection (urethra, } \\
\text { cervix, rectum, and pharynx) }\end{array}$ & $\begin{array}{l}\text { Ceftriaxone 500mg, intramuscular (IM), a single dose plus Azithromycin 500mg, two pills, per os (PO), a } \\
\text { single dose }\end{array}$ \\
\hline Disseminated gonococcal infection & $\begin{array}{l}\text { Ceftriaxone 1g, IM or intravenous (IV), per day, completing at least seven days of treatment plus } \\
\text { Azithromycin 500mg, two pills, PO, a single dose }\end{array}$ \\
\hline Chlamydia or mycoplasma infection & $\begin{array}{l}\text { Azithromycin } 500 \mathrm{mg} \text {, two tablets, PO, a single dose or Doxycycline 100mg, PO, twice a day, for seven days } \\
\text { (except pregnant women) }\end{array}$ \\
\hline Neonatal ophthalmia & Treatment \\
\hline Prevention of neonatal ophthalmia & $\begin{array}{l}\text { Silver nitrate at } 1 \% \text { (Crede's method), single application, within the first hour after birth; or Tetracycline at } \\
1 \% \text { (eye drops), single application, within the first hour after birth }\end{array}$ \\
\hline Treatment of neonatal ophthalmia & Ceftriaxone 25-50mg/kg/day, IM, maximum 125mg in single dose \\
\hline
\end{tabular}

Source: adapted from Clinical Protocol and Treatment Guidelines for Comprehensive Health Care for People with Sexually Transmitted Infections,202033.

Notes: a) In cases of mycoplasma, azithromycin is preferred, as doxycycline presents high levels of resistance; b) Local instillation of physiological solution, each hour; local penicillin instillation is recommended; in unsatisfactory therapeutic response cases, consider the hypothesis of simultaneous chlamydia infection.

FIGURE 2: Gonorrhea and chlamydia treatment. 
Symptoms persisting after the treatment of $N$. gonorrhoeae must be assessed through culture and test for determining the susceptibility of gonococcus to the antimicrobial drugs. We highlight that other microorganisms may also cause persistent cervicitis. Therapeutic failure must be considered for people who continue to present symptoms three to five days after treatment and without sexual contact within such period, as well as for people with a positive cure test (positive culture after 72 hours or positive NAAT at least seven days after the treatment), in case there is no report of sexual contact within such period ${ }^{33}$.

\section{SURVEILLANCE, PREVENTION, AND CONTROL}

As cervicitis is usually caused by an IST, it is essential to reinforce using condoms in all sexual intercourses. If a person is diagnosed with an STI, their recent sexual partners must also be tested and treated with the scheme aforementioned ${ }^{33}$.

Patients with positive tests must be advised to refrain from sexual contact for seven days after the treatment and resolve possible symptoms ${ }^{33,35}$. It is essential to offer information on the infections, including details on transmission, prevention, and complications, and advising all sexual partners ${ }^{33}$. The provision of verbal and written information, in addition to testing for other STI, such as gonorrhea, syphilis, HIV, and hepatitis B, among others, is recommended.

Sexual contacts must be encouraged to take tests, in addition to receiving advice and treatment for Chlamydia infection and other STI ${ }^{35-39}$. All sexual contacts of the six months before starting symptoms or performing diagnostic must ideally be evaluated, tested, and treated ${ }^{37,40}$.

The tests for control of cure of non-complicated urogenital or rectal $C$. trachomatis and $N$. gonorrhoeae infections are not routinely recommended for people treated with first-line schemes. However, they can be conducted during pregnancy, in cases of complicated infections or persistence of symptoms ${ }^{32}$. In situations of Chlamydia infection, extragenital infections may also be considered for investigation, mainly when azithromycin has been administered for treatment of rectal infections ${ }^{38}$.

When recommended, the test for cure control for Chlamydia should be performed four weeks after completion of therapy and through molecular tests ${ }^{37,38}$. The control test for detection of reinfection within three to six months may be ideally offered to young women and men (younger than 25 years old), presenting positive results for C. trachomatis ${ }^{33,37}$.

C. trachomatis, M. genitalium, and N. gonorrhoeae are not on the list of compulsory notification diseases of the Brazilian Ministry of Health, but the states and local governments can notify them.

Regarding $N$. gonorrhoeae, due to the development of high resistance to antimicrobial drugs, WHO has a program for worldwide surveillance of the gonococcal susceptibility to drugs, the Gonococcal Antimicrobial Surveillance Program (GASP). Brazil participates in this program, through the SenGono (Gonococcal Sensitivity) Project, which carries out this surveillance at the national level from samples of male urethral discharge, as recommended by $\mathrm{WHO}^{41}$. In a complementary way, within the scope of SenGono Project, the etiological agents of male urethral discharge are also being researched, which are the same pathogens present in cases of cervicitis - through the molecular tests performed with biological samples collected in all sites of the project ${ }^{42}$.

\section{SPECIAL POPULATIONS}

\section{Pregnant women and newborns}

The gonococcal and Chlamydia infections during pregnancy may be related to preterm births, premature rupture of membrane, fetal losses, intrauterine growth retardation, and postpartum endometritis, in addition to newborn conjunctivitis and pneumonia ${ }^{43-46}$.

In newborns, the main clinical manifestation is conjunctivitis, and there can be septicemia, arthritis, scalp abscesses, pneumonia, meningitis, endocarditis, and stomatitis ${ }^{47}$. Neonatal ophthalmia occurs in the first month of life, and, in case it is not treated, it can lead to blindness, mostly when caused by $N$. gonorrhoeae. For this reason, the disease must be treated immediately to prevent eye damage. Usually, the newborn is taken to the health service due to eyelids erythema and edema and conjunctive or mucopurulent material in the eyes. Chlamydia conjunctivitis is much less severe, and its incubation period ranges from five to 14 days $^{33}$. The relative frequency of eye infection by both etiologic agents depends on their prevalence in pregnant women and on the use of eye prophylaxis within an hour after birth ${ }^{33}$.

When available, research must be carried out for $N$. gonorrhoeae and C. trachomatis through molecular biology in a first prenatal medical appointment. The treatment is recommended for noncomplicated urogenital infection by $C$. trachomatis during pregnancy and breastfeeding. The test for control of cure must also be conducted if it is available. Azithromycin was considered safe and efficient according to clinical experience, and WHO also recommended it during pregnancy ${ }^{33}$.

\section{HIV infections}

STI are considered one of the main factors facilitating HIV transmission. The HIV infection changes the natural course of many infections, increasing their duration and making them more resistant or making them more recurrent and keeping a synergy between the HIV infection and other STI ${ }^{48,49}$. The cervix is a common and welldocumented place for HIV transmission. The invasive intracellular pathogeny of $C$. trachomatis may cause substantial damages to the endocervical epithelium, making infection by HIV infection easier ${ }^{50}$.

According to international studies, chlamydia infection prevalence in women living with HIV may vary from $2.0 \%$ to $10.0 \%^{51-53}$ up to $18.1 \%^{52}$. A study in Thailand showed a prevalence rate of $9.7 \%$ for Chlamydia among 824 women infected with $\mathrm{HIV}^{54}$. In Brazil, the prevalence can vary between $2.1 \%$ and $17 . \%^{8,55-57}$, depending on the place, the diagnostic method and sample type used. Regarding $N$. gonorrhoeae, the molecular mechanism associated with the increase of HIV transmission induced by the gonococcus is still not widely defined due to a proper in vitro model's unavailability. However, there is a hypothesis that this bacterial infection promotes the increased recruitment 
of endocervical $\mathrm{CD} 4 \% \mathrm{~T}$ cells, providing more targets for the activation of HIV- $1^{58}$. The prevalence of gonorrhea in Brazil varies from $0.5 \%$ to $0.9 \%$ in this group ${ }^{8,55}$.

Chlamydia and gonorrhea infections may present a more severe evolution and higher indexes of complications when they occur in women living with $\mathrm{HIV}^{59-61}$.

A cohort study conducted in women infected with HIV who have cervicitis by $M$. genitalium showed a prevalence of $7.4 \%$, indicating that $M$. genitalium is a frequent coinfection in women living with $\mathrm{HIV}^{62}$. The association between HIV infection and the infections causing cervicitis, in addition to the combined epidemiology, takes place partially due to the fact that these STI have common sexual risk behavior factors, such as multiple sexual partners ${ }^{61}$. The criteria for diagnosing and treating cervicitis for people living with HIV are the same ones used in those without HIV ${ }^{63}$.

\section{ADOLESCENTS}

Adolescents present higher risk of getting STI, including $N$. gonorrhoeae and C. trachomatis infections, both from behavioral and biological perspectives. Adolescents are more likely to risky sexual behavior, such as simultaneous partners or sexual intercourses without condoms. Besides, adolescents present a lower probability of accessing and using sexual health services in comparison with adults ${ }^{64,65}$. Such factors lead to a higher chance of exposure and a lower likelihood of diagnostic and treatment. From the biological point of view, female adolescents are particularly susceptible to STI due to the lower production of cervical mucus and increased cervical ectopy ${ }^{66}$. Therefore, in case they are exposed to an STI, adolescents are more likely to get infected than adults, as the columnar epithelium does not have the immunological defense ability of epithelial cells ${ }^{64,65}$. The criteria for diagnosing and treating cervicitis for adolescents are the same in women in general ${ }^{64}$.

\section{ACKNOWLEDGMENTS}

The authors acknowledge the substantial contribution to this work by the technical group of specialists responsible for developing the PDCT for Comprehensive Health Care for People with STI 2020.

\section{ORCID}

Angélica Espinosa Miranda - 0000-0002-5556-8379

Mariângela Freitas da Silveira - 0000-0002-2861-7139

Valdir Monteiro Pinto - 0000-0002-6880-7607

Geralda Carolina Alves - 0000-0001-9842-3834

Newton Sergio de Carvalho - 0000-0001-7561-4566

\section{AUTHORS' CONTRIBUTIONS}

Miranda AE, Silveira MF, Pinto VM, Alves GC, and Carvalho NS contributed equally to designing, drafting, and critically reviewing the manuscript. All the authors approved the final version and are responsible for all aspects, including accuracy and integrity.

\section{REFERENCES}

1. Brasil. Ministério da Saúde. Portaria MS/SCTIE $n^{\circ} 42$, de 5 de outubro de 2018. Torna pública a decisão de aprovar o Protocolo Clínico e Diretrizes Terapêuticas para Atenção Integral às Pessoas com Infecções Sexualmente Transmissíveis (IST), no âmbito do Sistema Único de Saúde - SUS [Internet]. Diário Oficial da União, Brasília (DF), 2018 Oct 8 [cited 2020 Sep 25];Seção I:88. Available from: http://bvsms.saude. gov.br/bvs/saudelegis/sctie/2018/prt0042_08_10_2018.html

2. Brunham RC, Paavonen J, Stevens CE, KiviatN,KuoCC,CritchlowCW,et al. Mucopurulent cervicitis - the ignored counterpart in women of urethritis in men. N Engl J Med [Internet]. 1984 Jul [cited 2020 Sep 29;311(1):1-6. Available from: https://doi.org/10.1056/nejm198407053110101

3. Lusk MJ, Konecny P. Cervicitis: a review. CurrOpin Infect Dis [Internet].2008 Feb [cited 2020 Sep 28];21(1):49-55. Available from: https://doi.org/10.1097/qco.0b013e3282f3d988

4. Lusk MJ, Garden FL, Rawlinson WD, Naing ZW, Cumming RG, Konecny P. Cervicitis an etiology and case definition: a study in Australian women attending sexually transmitted infection clinics. SexTransmInfect [Internet].2016 May [cited 2020 Sep 28];92(3):175-81. Available from: https://doi.org/10.1136/sextrans-2015-052332

5. Carvalho NS, Palú G, Witkin SS. Mycoplasma genitalium, a stealth female reproductive tract. EurJClinMicrobiol Infect Dis [Internet]. 2020 Feb [cited 2020 Sep 28];39(2):229-34. Available from: https://doi. org/10.1007/s10096-019-03707-8

6. Graves KJ, Ghosh AP, Kissinger PJ, Muzny CA. Trichomonasvaginalis virus: a review of the literature. Int J STD AIDS [Internet]. 2019 Apr [cited 2020 Sep 28];30(5):496-504. Available from: https://doi. org/10.1177/0956462418809767

7. Taylor SN. Cervicitis of unknown etiology. Curr Infect Dis Rep [Internet].2014 Jul [cited 2020 Sep 28];16(7):409. Available from: https://doi.org/10.1007/s11908-014-0409-x

8. Rowley J, Hoorn SV, Korenromp E, Low N, Unemo M, Abu-Raddad LJ, et al. Chlamydia, gonorrhoea, trichomoniasis and syphilis: global prevalence and incidence estimates, 2016. Bull WorldHealthOrgan [Internet]. 2019 Aug [cited 2020 Sep 25];97(8):548-62. Available from: https://dx.doi.org/10.2471\%2FBLT.18.228486

9. Miranda AE, Silveira MF, Travassos AG, Tenório T, Val ICCD, Lannoy L, et al. Prevalence of Chlamydia trachomatis and Neisseria gonorroheae and associated factors among women living with Human Immunodeficiency Virus in Brazil: a multicenter study. Braz J Infect Dis [Internet]. 2017Jul-Aug[cited 2020 Sep 28];21(4):402-7. Available from: https://doi.org/10.1016/j.bjid.2017.03.014

10. Pinto VM, Szwarcwald CL, Baroni C, Stringari LL, Inocêncio LA, Miranda AE. Chlamydia trachomatis prevalence and risk behaviors in parturient women aged 15 to 24 in Brazil. Sex Transm Dis [Internet]. 2011 Oct [cited 2020 Sep 28];38(10):957-61. Available from: https://doi. org/10.1097/olq.0b013e31822037fc

11. Schmidt R, Muniz RR, Cola E, Stauffert D, Silveira MF, Miranda AE. Maternal chlamydia trachomatis infections and preterm births in a university hospital in Vitoria, Brazil. PLoS One [Internet].2015 Oct [cited 2020 Sep 25];10(10):e0141367. Available from: https://dx.doi. org/10.1371\%2Fjournal.pone.0141367

12. Silveira MF, Sclowitz IK, Entiauspe LG, Mesenburg MA, Stauffert D, Bicca GL, et al. Chlamydia trachomatis infection in young pregnant women in Southern Brazil: across-sectional study. CadSaúde Pública [Internet].2017 Feb [cited 2020 Sep 25];33(1):e00067415. Available from: https://doi.org/10.1590/0102-311x00067415

13. Barcelos MR, Merçon-de-Vargas, Baroni C, Miranda AE. Genital infections in women attending a primary unit of health: prevalence and risk behaviors. RevBrasGinecol Obstet [Internet].2008 Jul [cited 2020 Sep 28];30(7):34954. Available from: http://dx.doi.org/10.1590/S0100-72032008000700005 
14. Carvalho NS, Pegoraro MG, Takimura M, Oliveira Jr FC. Prevalence of chlamydia trachomatis at pregnants admitted in the public health maternity. J BrasDoençasSexTransm [Internet]. 2010 [cited 2020 Sep 28];22(3):141-4. Available from: http://www.dst.uff.br/revista22-3-2010/ Prevalencia\%20da\%20infeccao\%20por\%20clamidia.pdf

15. Piazzeta RC, Carvalho NS, Andrade RP, Piazzetta G, Piazzetta SR, Carneiro R. Prevalence of chlamydia trachomatis and neisseria gonorrhoea infections in sexual actives young women at a Southern Brazilian city. RevBrasGinecolObstet [Internet].2011 Nov [cited 2020 Sep 28];33(11):328-33. Available from: https://doi.org/10.1590/S010072032011001100002

16. Lima YA, Turchi MD, Fonseca ZC, Garcia FLB, Cardoso FAB, Reis MNG, et al.Sexually transmitted bacterial infections among young women in Central Western Brazil. Int J InfectDis [Internet].2014 Aug [cited 2020 Sep 28];25:16-21. Available from: https://doi.org/10.1016/j. ijid.2014.03.1389

17. Azevedo MJN, Nunes SDS, Oliveira FG, Rocha DAP. High prevalence of Chlamydia trachomatis in pregnant women attended at primary health care services in Amazon, Brazil. RevInstMedTrop [Internet].2019 Feb [cited 2020 Sep 28];61:e6. Available from: https://doi.org/10.1590/s1678$\underline{9946201961006}$

18. Stamm WE. Chlamydia trachomatis infections of the adult. In: Holmes KK,MardhPA,SparlingPF, et al. Sexually transmitted diseases. 3rd ed. Nova Iorque: MacGraw-Hill, USA; 1999.

19. Patton DL. Immunopathology and histopathology of experimental chlamydial salpingitis. Rev Infect Dis [Internet].1985 Nov-Dec [cited 2020 Sep 28];7(6):746-53. Available from: https://doi.org/10.1093/ clinids/7.6.746

20. Paavonen J, Eggert-Kruse W. Chlamydia trachomatis: impact on human reproduction. Hum Reprod Update [Internet]. 1999 Sep-Oct [cited 2020 Sep 28];5(5):433-47. Available from: https://doi.org/10.1093/ humupd/5.5.433

21. Mardh PA. Tubal factor infertility, with special regard to chlamydial salpingitis. Curr Opin Infect Dis [Internet].2004 Feb [cited 2020 Sep 28];17(1):49-52. Available from: https://doi.org/10.1097/00001432$\underline{200402000-00010}$

22. Bakken IJ, Ghaderi S. Incidence of pelvic inflammatory disease in a large cohort of women tested for Chlamydia trachomatis: a historical follow-up study. BMC Infect Dis [Internet].2009 Aug [cited 2020 Sep 28];9:130. Available from: https://doi.org/10.1186/1471-2334-9-130

23. Land JA, Van Bergen JEAM, Morré SA, Postma MJ, et al. Epidemiology of Chlamydia trachomatis infection in women and the cost-effectiveness of screening. Hum Reprod Update [Internet]. 2010 Mar-Apr [cited 2020 Sep 28];16(2):189-204. Available from: https://doi.org/10.1093/humupd/ dmp035

24. Currie MJ, Bowden FJ. The importance of chlamydial infections in obstetrics and gynaecology: an update. Aust N Z J Obstet Gynaecol [Internet].2007 Feb [cited 2020 Sep 28];47(1):2-8. Available from: https://doi.org/10.1111/j.1479-828x.2006.00670.x

25. Lamontagne DS, Baster K, Emmet L, Nichols T, Randall S, McLean L, et al. Incidence and reinfection rates of genital chlamydial infection among women aged 16-24 years attending general practice family planning and genitourinary medicine clinics in England: a prospective cohort study. Sex Transm Infect [Internet]. 2007Jul [cited 2020 Sep 28];83(4):292-303. Available from: https://doi.org/10.1136/sti.2006.022053

26. Skjeldestad FE, Marsico MA, Canta HL, Nordbø SA, StørvoldG. Incidence and risk factors for genital Chlamydia trachomatis infection: a 4-year prospective cohort study. Sex Transm Dis [Internet]. 2009 May [cited 2020 Sep 28];36(5):273-9. Available from: https://doi.org/10.1097/ olq.0b013e 3181924386
27. Wetmore CM, Manhart LE, Wasserheit JN. Randomized controlled trials of interventions to prevent sexually transmitted infections: learning from the past to plan for the future.Epidemiol Rev [Internet]. 2010 Apr [cited 2020 Sep 28];32(1):121-36. Available from: https:// dx.doi.org/10.1093\%2Fepirev\%2Fmxq010

28. Ryan CA, Courtois BN, Hawes SE, Stevens CE, Eschenbach DA, Holmes $\mathrm{KK}$. Risk assessment, symptoms, and signs as predictors of vulvovaginal and cervical infections in an urban US STD clinic: implications for use of STD algorithms. Sex Transm Inf.1998 Jun;74(Suppl 1):S59-76.

29. Bourgeois A, Henzel D, Dibanga L, Mouelet L-M, Peeters H, Coulaud JP, et al.Prospective evaluation of a flow chart using a risk assessment for the diagnosis of STDs in primary healthcare centers in Libreville, Gabon. Sex Transm Inf. 1998 Jun;74(Suppl 1):S128-31.

30. Mayaud P, Ka-gina G, Cornelissen J, Todd J, KaatanoL, West B, et al. Validation of a WHO algorithm with risk assessment for the clinical management of vaginal discharge in Mwanza, Tanzania. Sex Transm Inf. 1998 Jun;74(Suppl 1):S77-84.

31. Organização Mundial de Saúde - OMS. Diagnóstico laboratorial de doenças sexualmente transmissíveis, incluindo o vírus da imunodeficiência humana [Internet]. Brasília: OMS;Ministério da Saúde; 2013 [cited 2020 Sep 28].255 p. Available from: https://apps.who.int/iris/ bitstream/handle/10665/85343/9789241505840 por.pdf;jsessionid

32. Meyer T. Diagnostic procedures to detect chlamydia trachomatis infections. Microorganisms [Internet].2016 Sep [cited2020 Sep 28];4(3):25. Available from: http://www.mdpi.com/journal/microorganisms

33. Ministério da Saúde (BR). Secretaria de Vigilância em Saúde. Protocolo clínico e diretrizes terapêuticas para atenção integral às pessoas com infecções sexualmente transmissíveis (PCDT-IST) [Internet]. Brasília: Ministério da Saúde; 2020 [cited 2020 Sep 28]. 248 p. Available from: http://www.aids.gov.br/pt-br/pub/2015/protocolo-clinico-e-diretrizesterapeuticas-para-atencao-integral-pessoas-com-infeccoes

34. Ministério da Saúde (BR). Secretaria de Ciência, Tecnologia e Insumos Estratégicos. Comissão Nacional de Incorporação de Tecnologias no SUS (Conitec). Ceftriaxona 500mg para tratamento da Neisseriagonorrhoeae resistente àciprofloxacina: relatório de recomendação [Internet].Brasília: Ministério da Saúde; 2015 [cited 2020 Sep 29]. 29 p. Available from: http://conitec.gov.br/images/Relatorios/2015/Relatorio_Ceftriaxona Gonorreia final.pdf

35. Workowski KA, Bolan GA. Sexually transmitted diseases treatment guidelines. MMWR [Internet]. 2015 Jun [cited 2020 Sep 29];64(RR3);1-137. Available from: https://www.cdc.gov/mmwr/preview/mmwrhtml/rr6403al.htm

36. Dize L, Barnes P Jr, Barnes M, Hsieh YH, Marsiglia V, Duncan D, et al. Performance of self-collected penile-meatal swabs compared to cliniciancollected urethral swabs for the detection of Chlamydia trachomatis, Neisseria gonorrhoeae, Trichomonasvaginalis, and Mycoplasma genitalium by nucleic acid amplification assays. DiagnMicrobiol Infect Dis [Internet].2016 Oct [cited 2020 Sep 29];86(2):131-5. Available from: https://doi.org/10.1016/j.diagmicrobio.2016.07.018

37. Lanjouw E, Ouburg S, Vries HJ, Stary A, Radcliffe K, Unemo M. 2015 European guideline on the management of Chlamydia trachomatis infections.IntJSTDAIDS[Internet].2016Apr[cited2020Sep29];27(5):33348. Available from: https://doi.org/10.1177/0956462415618837

38. Steedman NM, McMillan A. Treatment of asymptomatic rectal Chlamydia trachomatis: is single-dose azithromycin effective? Int J STD AIDS [Internet]. 2009 Jan [cited 2020 Sep 29];20(1):16-8. Available from: https://doi.org/10.1258/ijsa.2008.008211

39. Renault CA, Israelski DM, Levy V, Fujikawa BK, Kellogg TA, Klausner JD. Time to clearance of Chlamydia trachomatis ribosomal RNA in women treated for chlamydial infection. Sex Health [Internet]. 2011 Mar [cited 2020 Sep 29];8(1):69-73. Available from: https://doi.org/10.1071/sh10030 
40. Dukers-Muijrers NH, Morré SA, Speksnijder A, van der Sande MA, Hoebe CJ. Chlamydia trachomatis test-of-cure cannot be based on a single highly sensitive laboratory test taken at least 3 weeks after treatment. PLoS One [Internet]. 2012 [cited 2020 Sep 29];7(3):e34108. Available from : https://doi.org/10.1371/journal.pone.0034108

41. Wilson TE, Hogben M, Malka ES, Liddon N, McCormack W, Rubin SR, et al. A randomized controlled trial for reducing risks for sexually transmitted infections through enhanced patient-based partner notification. Am J Public Health [Internet]. 2009 Apr [cited 2020 Sep 29];99(suppl 1):S104-10. Available from: https://dx.doi. org/10.2105\%2FAJPH.2007.112128

42. Brasil. Ministério da Saúde. Portaria MS/GM no 1.553, de 17 de junho de 2020. Altera a Portaria de Consolidação ${ }^{\circ}$ 5/GM/MS, de 28 de setembro de 2017, para instituir a Vigilância Sentinela da Síndrome do Corrimento Uretral Masculino (VSCUM) [Internet]. Diário Oficial da União, Brasília (DF), 2020 Jun 17 [cited 2020 Sep 29]:Seção I:61. Available from: http://bvsms.saude.gov.br/bvs/saudelegis/gm/2020/prt1553 $18 \quad 06 \quad 2020$. $\underline{\mathrm{html}}$

43. Bazzo ML, Golfetto L, Gaspar PC, Pires AF, Ramos MC, Franchini $\mathrm{M}$, et al. First nationwide antimicrobial susceptibility surveillance for Neisseria gonorrhoeae in Brazil, 2015-16. J Antimicrob Chemother [Internet]. $2018 \mathrm{Jul}$ [cited $2020 \mathrm{Sep}$ 29];73(7):1854-61. Available from: https://doi.org/10.1093/jac/dky090

44. Mann, JR, Mcdermott S, Gill T. Sexually transmitted infection is associated with increased risk of preterm birth in South Carolina women insured by Medicaid. J Matern Fetal Neonatal Med [Internet]. 2010 Jun [cited 2020 Sep 29];23(6):563-8. Available from: https://doi. org $110.3109 / 14767050903214574$

45. Andrews WW, Klebanoff MA, Thom EA, Hauth JC, Carey JC, Meis PJ,al. Midpregnancy genitourinary tract infection with Chlamydia trachomatis: association with subsequent preterm delivery in women with bacterial vaginosis and Trichomonas vaginalis. Am J Obstet Gynecol [Internet]. 2006 Feb [cited 2020 Sep 29];194(2):493-500. Available from: https://doi.org/10.1016/j.ajog.2005.08.054

46. Silveira MF, Ghanem KG, Erbelding EJ, Burke AE, Johnson HL, Singh $\mathrm{RH}$, et al. Chlamydia trachomatis infection during pregnancy and the risk of preterm birth: a case-control study. Int J STD AIDS [Internet]. 2009 Jul [cited 2020 Sep 29];20(7):465-9. Available from: https://doi. org/10.1258/ijsa.2008.008388

47. Rours GIJG, Krijger RR, Ott A, Hendrina FMW, Groot R, Zimmermann LJ, et al. Chlamydia trachomatis and placental inflammation in early preterm delivery. EurJEpidemiol [Internet]. 2011 May [cited 2020 Sep 29];26(5):421-8. Available from: https://dx.doi. org/10.1007\%2Fs10654-011-9569-2

48. Fleming DT, Wasserheit JN. From epidemiological synergy to public health policy and practice: the contribution of other sexually transmitted diseases to sexual transmission of HIV infection. SexTransm Infect [Internet].1999 Feb [cited 2020 Sep 29];75(1):3-17. Available from: https://doi.org/10.1136/sti.75.1.3

49. Mwatelah R, McKinnon LR, Baxter C, Abdool Karim Q, Abdool Karim SS.Mechanisms of sexually transmitted infection-induced inflammation in women: implications for HIV risk. J Int AIDS Soc [Internet]. 2019 Aug [cited 2020 Sep 29];22(Suppl 6):e25346. Available from: https://doi. org/10.1002/jia2.25346

50. McClean H, Carne CA, Sullivan AK, Radcliffe KW, Ahmed-Jushuf I, National Audit Group of British Association for Sexual Health and HIV. Chlamydial partner notification in the British Association for Sexual Health and HIV (BASHH) 2011 UK national audit against the BASHH Medical Foundation for AIDS and Sexual Health Sexually Transmitted Infections Management Standards. Int J STD AIDS [Internet].2012 Oct [cited 2020 Sep 29];23(10):748-52. Available from: https://doi.org/10.1258/ijsa.2012.012035
51. Peipert JF. Clinical practice. Genital chlamydial infections. N Engl J Med [Internet]. 2003 Dec [cited 2020 sep 29];349(25):2424-30. Available from: https://doi.org/10.1056/nejmcp030542

52. Schust DJ, Ibana JA, Buckner HR, Ficarra M, Sugimoto J, Amedee AM. Potential mechanisms for increased HIV-1 transmission across the endocervical epithelium during C. trachomatis infection. Curr HIV Res [Internet]. 2012 Apr [cited 2020 Sep 29];10(3):218-27. Available from: https://doi.org/10.2174/157016212800618093

53. Manning SE, Pfeiffer MR, Nash D, Branco S, Sackoff J, Schillinger J. Incident sexually transmitted infections among persons living with diagnosed HIV/AIDS in New York City, 2001-2002: a populationbased assessment. SexTransm Dis [Internet]. 2007 Dec [cited 2020 Sep 29];34(12):1008-15. Available from: https://doi.org/10.1097/ olq.0b013e 3180 eaa 243

54. Srifeungfung S, Roongpisuthipong A, Asavapiriyanont S, Lolekha R, Tribuddharat C, Lokpichart S, et al. Prevalence of Chlamydia trachomatis and Neisseria gonorrhoeae in HIV-seropositive patients and gonococcal antimicrobial susceptibility: an update in Thailand. JapanJInfectDis [Internet]. 2009 Oct [cited 2020 Sep 29];62(6):467-70. Available from: https://europepmc.org/article/med/19934542

55. Scheer S, Chu PL, Klausner JD, Katz MH, Schwarcz SK. Effect of highly active antiretroviral therapy on diagnoses of sexually transmitted diseases in people with AIDS. Lancet [Internet]. 2001 Feb [cited 2020 sep 29];357(9254):432-5. Available from: https://doi.org/10.1016/s0140$\underline{6736(00) 04007-1}$

56. Adachi K, Klausner JD, Bristow CC, Xu J, Ank B, Morgado ML, et al. Chlamydia and gonorrhea in HIV-infected pregnant women and infant HIV transmission. SexTransm Dis [Internet]. 2015 Oct [cited 2020 sep 29];42(10):554-65. Available from: https://doi.org/10.1097/ olq.0000000000000340

57. Pinto VM, Tancredi MV, Silva RJC, Khoury Z, Buchalla CM. Prevalência e fatores associados à infecção por Chlamydia trachomatis em mulheres com HIV em São Paulo. RevSocBrasMedTrop [Internet]. 2016 maio-jun [cited 2020 sep 29];49(3):312-8. Available from: https:// doi.org/10.1590/0037-8682-0169-2016

58. Silva LC, Miranda AE, Batalha RS, Sabino CCD, Dib E, Costa CM, et al. Chlamydia trachomatis infection among HIV-infected women attending an AIDS clinic in the city of Manaus, Brazil. Braz J Infect Dis [Internet]. 2012 [cited 2020 sep 29];16(4):335-8. Available from: https:// doi.org/10.1016/j.bjid.2012.06.023

59. Brandão VCRA, Lacerda HR, Ximenes RAA. Frequência de papilomavírus humano (HPV) e Chlamydia trachomatis em gestantes. Epidemiol Serv Saúde [Internet]. 2010 Jan-Mar [cited 2020 Sep 29];19(1):43-50. Available from: http://dx.doi.org/10.5123/S1679$\underline{49742010000100006}$

60. Sanyal A, Shen C, Ding M, Reinhart TA, Chen Y, Sankapal S, et al. Neisseria gonorrhoeae uses cellular proteins CXCL10 and IL8 to enhance HIV-1 transmission across cervical mucosa. AmJReprodImmunol [Internet].2019 Jun [cited 2020 Sep 29];81(6):e13111. Available from: https://doi.org/10.1111/aji.13111

61. Reda S, Gonçalves FA, Mazepa MM, Carvalho NS. Women infected with HIV and the impact of associated sexually transmitted infections. Int J GynecolObstet [Internet].2018 Aug [cited 2020 Sep 29];142(2):1437. Available from: https://doi.org/10.1002/ijgo.12507

62. Dehon PM, Hagensee ME, Sutton KJ, Oddo HE, Nelson N, McGowin CL. Histological evidence of chronic mycoplasma genitalium-induced cervicitis in HIV-infected women: a retrospective cohort study. J Infect Dis [Internet]. 2016 Jun [cited 2020 Sep 29];213(11):1828-35. Available from: https://doi.org/10.1093/infdis/jiw025 
63. Joyee AG, Thyagarajan SP, Reddy EV, Venkatesan C, Ganapathy M. Genital chlamydial infection in STD patients: its relation to HIV infection. Indian JMedMicrobiol [Internet]. 2005 Jan [cited 2020 Sep 29];23(1):3740. Available from: https://doi.org/10.4103/0255-0857.13871

64. Hunter P, Dalby J, Marks J, Swain GR, Schrager S.Screening and prevention of sexually transmitted infections. PrimCare [Internet]. 2014 Jun [cited 2020 Sep 29];41(2):215-37. Available from: https://doi. org/10.1016/j.pop.2014.02.003
65. Steinberg L. Cognitive and affective development in adolescence. TrendsCognSci [Internet]. 2005 Feb [cited 2020 Sep 29];9(2):69-74. Available from: https://doi.org/10.1016/j.tics.2004.12.005

66. Burchell AN, Winer RL, Sanjosé S, Franco EL. Chapter 6: Epidemiology and transmission dynamics of genital HPV infection. Vaccine [Internet]. 2006 Aug [cited 2020 Sep 29];24 Suppl 3:S52-61. Available from: https://doi.org/10.1016/j.vaccine.2006.05.031 